\title{
Role of Fat Feeding on the Diabetic Albino Rats
}

Ahmed H. Abdel-Rahman H. El-Rashedy ${ }^{1 *}$, Mohamed H. Mostafa Wahdan², Khaled Abdel-Fattah R. El-Sabban ${ }^{3}$, Mohamed Ali Khadrawy $^{4}$, Tamer M. M. Abu-Amara ${ }^{5}$, Hanan A.Al-Hamaky ${ }^{6}$ and Nahid M. El-Hagar ${ }^{7}$

${ }^{1}$ Histopathology and cytopathology, Taif University, KSA

${ }^{2}$ Electron microscopic assessment, Taif University, KSA

${ }^{3}$ Department of medicine, Taif University, KSA

${ }^{4}$ Medical statistics, Taif University, KSA

${ }^{5}$ Histology, Al-Azhar University, Egypt

${ }^{6}$ Histopathology and cytopathology, Taibah University, KSA

${ }^{7}$ Department of medicine, Taif University, KSA

\section{Abstract}

Aim of the work: The nutrition of developing countries are rapidly changed and associated with high incidence of obesity as well as the metabolic syndrome and type 2diabetes. There is an increased intake of high caloric foods rich in refined carbohydrates, fats and red animal proteins instead of low caloric foods rich in fibers and containing low fats. This study aimed at the evaluation of effect of animal fats on the diabetic rats.

Material and methods: This study was performed on forty eight albino rats (their body weight was $190 \pm 10$ grams) divided equally into four groups. Two groups (III \& IV) were given intravenous streptozotocin in a concentration of $60 \mathrm{mg} / \mathrm{Kg}$. B.W. for three days in order to induce diabetes through the destruction of pancreatic islet beta cells. Non-diabetic rats (group I) were given the laboratory diet (LD) while the non-diabetic second group of rats received an emulsion rich in fat. Third group diabetic animals were fed on the laboratory diet (LD) while group IV diabetic rats were received high-fat (HF) emulsion in the same dosage as group II. C-peptide $(\mathrm{ng} / \mathrm{ml})$, blood glucose $(\mathrm{mg} /$ $\mathrm{dl}$ ), serum triglycerides (TG; $\mathrm{mmol} / \mathrm{l})$ and total cholesterol (TC; $\mathrm{mmol} / \mathrm{l}$ ) were assessed before the beginning of this experiment and also once every two weeks for four months in non-fasted diabetic and non diabetic counterparts. Moreover, kidneys and liver were examined histopathologically to detect fatty intracellular accumulation and any other changes.

Results: The study revealed severe hyperglycemia in group IV than in group III while the levels were being within normal in group II and control group. In addition, hyperlipidemia was much greater in group IV diabetic rats compared to groups II and III while the control group had normal serum lipid levels. Moreover, much reduction in C-peptide values was detected in fourth than in third group of rats. In addition, the group II rats had slightly increased C-peptide levels while this peptide was normal in the control group. The histopathological and ultrastructural fat accumulation within the liver and kidneys was more severely detected in diabetic fat-fed rats than nondiabetic fatfed animals. Moreover, intracellular fatty infiltrative features had been detected in a greatly lesser extent within the diabetic nonfat-fed liver and kidneys. In contrast, the control group showed no hepatic and renal parenchymal fatty infiltration.

Conclusion: These findings potentially conclude that hyperlipidemia may lead to a significant renal and hepatic injury particularly with diabetes. Moreover, the fatty diet may aggravate the diabetic manifestations \& therefore enhancing its complications.

Keywords: Animal fatty diet; Diabetes; Serum chemistry; Histopathology

\section{Introduction}

Rapid nutritional modifications occur in the developing countries [1]. A change in these countries from a low-caloric foods containing low fat and high amount of fibers into a hypercaloric diet containing large quantities of refined carbohydrates, high total fat and red meats, along with low intakes of fiber is resorted to [2]. Widespread availability of unhealthy low-cost vegetable oils as well as their commercial use can lead to an increased dietary intake of fats and trans-fatty acids (TFAs) [3]. These faulty dietary habits contribute to high prevalence of metabolic syndrome, obesity and type 2 diabetes (T2D) triad [4]. Certain fatty acids are evidenced to influence the cellular metabolism through adjusting the equanimity between lipogenesis and fatty acid oxidation. Alteration of the amount and property of nutritional fats may modify the sensitivity of insulin [5]. Ingestion of large amount of fat is accompanied by high fasting serum insulin levels as well as lower sensitivity index of insulin [2]. Data from epidemiologic studies in developed nations showed more total fat consumption in T2D patients than in normoglycemic controls [6]. Individuals with good health are prone to develop an impaired glucose tolerance [7] while impaired glucose tolerated patients are liable to progress into T2D [2]. Impaired glucose-insulin-lipid metabolism may occur as a result of low insulin sensitivity, starting many metabolic events causing T2D and representing cardiovascular dangerous effects. This overall bulk of data, except for a few studies [8,9] shows an association of excess fat intake with obesity and glucose-insulin metabolic disruption, which may contribute to the development of T2D [2].

*Corresponding author: Ahmed H.Abdel-Rahman H Elrashedy, Professor and Consultant of Histopathology and Cytopathology, College of Medicine, Taif University, KSA, E-mail: dr.ahmed_elrashedy@yahoo.com

Received April 19, 2013; Accepted June 11, 2013; Published June 14, 2013

Citation: El-Rashedy AHARH, Mostafa Wahdan MH, El-Sabban KAFR, Khadrawy MA, Abu-Amara TMM, et al. (2013) Role of Fat Feeding on the Diabetic Albino Rats. J Cytol Histol 4: 176. doi:10.4172/2157-7099.1000176

Copyright: (c) 2013 El-Rashedy AHARH, et al. This is an open-access article distributed under the terms of the Creative Commons Attribution License, which permits unrestricted use, distribution, and reproduction in any medium, provided the original author and source are credited. 
International Monetary Fund [10] correlated the intake of fats and oils in developing countries with hyperglycemia and diabetes and detected its associations with either obesity or insulin resistance or metabolic syndrome. Misra et al. [11] mentioned more detailed reviews of Asian Indian and South Asian diets particularly regarding insulin resistance and Non-Communicable Diseases (NCDs). High-fat diets in spite of promoting weight gain as well as resistance to insulin and may be considered in T2D development, however, secular data are limited regarding the entire dietary fat's relationships with obesity and the metabolic syndrome. Also, no data are available regarding T2D in developing countries. Importantly, the cost and availability of fats and oils determine their usage in developing countries. For instance, because of the high cost of olive oil, it is used sparingly, while mustard, sunflower, and soybean oils are used widely because of their low cost [2]. The high intake of traditional diets (containing full fatty milk as well as high amounts of fats, and oils) was associated with an increased incidence of abdominal obesity in adult Mongolian females [12].

The general guidelines, from the international organizations (WHO/FAO), for fat intake in the developing countries, particularly in view of the rise of T2D and coronary heart diseases, should be individualized keeping in mind the local dietary and cooking practices as well as the use of cooking oils in these countries [13].

The notion that high-fat diets are associated with impaired insulin action is strongly supported [14]. Saturated fats are particularly associated with greatest harmful effects including high risk of developing cardiovascular disorders. It has recommended that the entire fat intake must not exceed thirty percent of calories and favored diets have to be low in saturated fat [15]. Anyway, the entire fat as part of total body energy has not been significant to avoid T2D [16].

It has been regarded that $\mathrm{T} 2 \mathrm{D}$, being a multi-etiological disorder, has many pathogenetic mechanisms to be developed [17]. The mechanism of resistance to insulin and intolerance to glucose involves communication of the signaling cellular proteins through cellular membranes, across the cytoplasm as well as across the nuclear receptors in several tissues with target effects in certain organs such as pancreas, kidney, liver and brain in addition to adipose and muscular tissues. Type 2 diabetes may be accompanied by multiple steps through which nutrient effects could occur and various nutrients may be significant. Since the diet has a different action on insulin in earlier and later stages of diabetes, high serum insulin level associating the normal and abnormal glucose tolerance indicates the dietary role in these stages of the disease particularly the later ones that are characterized with greater stress of pancreatic $\beta$-cells $[18,19]$.

The incidence of $\mathrm{T} 2 \mathrm{D}$ is rapidly progressive throughout the world. In addition to the genetic basis, T2D associating obesity results from multiple bad behavioral and environmental etiological factors like deficient life activities and high caloric intake [20]. The association of risky fat intake with diabetes has been statistically undervalued through the modification of nutrient fat value as a diabetic hazardous factor [21].

Moreover, intake of cereals or caloric diet is statistically confounding variable because of its independent relationship to the risk of diabetes [22].

C-peptide protein is synthesized together with insulin synthesis within the human body. Preproinsulin is firstly released together with C-peptide, A-chain and B-chain as well as a sequence of signals. Secondly, the sequence of signals breaks off to leave insulin precursor. Thirdly C-peptide protein detaches in order to leave both A- \& Bchains that produce the insulin. Insulin precursor; C-peptide, was firstly discovered since 1967 together with the revelation of insulin synthesis [23]. C-peptide protein acts as a significant link between Aand B- chains of insulin hormone. As well, this peptide promotes the effective assembly and folding as well as the insulin processing within B-cell endoplasmic reticulum [24].

The granules of pancreatic islets' B-cells store both insulin and C-peptide protein which are finally liberated into portal blood. C-peptide protein is considered as an indicator for the secretion of insulin and is valuable in understanding the disturbed physiological functions encountered in type 1diabetes (T1D) as well as T2D. Moreover, C-peptide protein has been discovered previously to affect both microvascular circulation and healthiness of tissue ${ }^{(25)}$. In addition, C-peptide protein bind to G-protein receptor found on the surface of many cells like the neurons, renal tubular lining cells, fibroblasts and vascular endothelial cells $[25,26]$. Intracellular calcium-dependent signaling pathways are activated upregulating the activities of certain enzymes such as endothelial nitric acid synthase (eNOS) and Sodium/ Potassium adenosine triphosphatase [27]. In type 1 diabetic patients, the activities of these two enzymes are reduced and being responsible for long - term neurological complications in those patients. Furthermore, the administration of C-peptide protein into type 1 diabetic animals has been associated with neurological and renal functional improvement $[28,29]$. Also, replacement C-peptide therapy of early neuropathy in diabetic animals has been accompanied with improvement of both functional and structural peripheral nerve impairment [27]. C-peptide protein therapy in nephropathic type 1 diabetic animals which had lack of C-peptide produced improvement in both renal functional and structural changes as well as reduction in the proteinuria and in diabetic glomerular changes following the expansion of the mesangial matrix [26].

The measurement of serum levels of C-peptide reflects the amount of pancreatic insulin synthesis since this peptide and this hormone are usually present in equal amounts. Because the concentration of insulin varies between the portal and the peripheral circulations, the serum levels of C-peptide substitute those of insulin to distinguish type 1 from type 2 diabetes. Since the pancreatic insulin release in type 1 diabetes is deficient, thus, the peptide level in this type of diabetes is usually declined. In contrast, the levels of $\mathrm{C}$-peptide with type 2 diabetes are either higher or within normal. Therefore, the blood levels of C-peptide can reflect the type of diabetes. Measurement of this peptide in the diabetic patients undergoing external insulin injection will also assist to know their actual pancreatic function by determining the amount of their own produced insulin. In addition, the detection of high serum C-peptide levels may probably denote a functioning B-cell pancreatic tumor termed as insulinoma whose cells release excess insulin. It has been stated, as well, that C-peptide may act as an anti-inflammatory and may help in smooth muscle repair [24].

C-peptide may be very important indicator of type 2 diabetes regarding insulin secretion as the normal peptide level may denote pancreatic release of ample amount of insulin to which the patient's body doesn't properly respond [30].

This study aimed at induction of diabetes experimentally to evaluate effective fat feeding's role on diabetic rats as well as its histopathological changes on the liver \& kidney depending on the hypothesis that the impairment or inhibition of receptor molecules that control the enzymes responsible for the oxidation and synthesis of fatty acids contributes to fat accumulation and infiltration. 


\section{Materials and Procedure}

\section{Studied animals \& chemicals}

The study is performed on forty eight Albino male rats of Westar strain ranging in their body weight between 180-200 grams. The animals were administrated food and water. The ordinary laboratory diet was formed of protein in 21 percent, fats in 5 percent, crude fiber in 4 percent, ash in 8 percent, calcium in 1 percent, phosphorus in 0.6 percent, glucose in 3.4 percent, vitamin in 2 percent and nitrogen free carbohydrates extract in 55 percent while vanaspati fatty acid and coconut oil fatty acid composition was mentioned by Saravanan et al. [31]. Housing of the rats in the plastic cages had carried out in controlled situations of cyclical 12 hours light and 12 hours dark as well as being found at a temperature ranged between $22-26^{\circ} \mathrm{C}$.

Sterile streptozotocin powders were provided by Pharmacia Company in vials each of which included one gram of active ingredient of streptozotocin in addition to 200 milligrams of citric acid. The drug was dissolved in distilled water and kept at cold temperature ranged between $2-8^{\circ} \mathrm{C}$ and remained away from the light in a refrigerator.

Indian vanaspati as well as Coconut oil were bought from Chidambaram, India while the triglyceride (TG) kit and total cholesterol kit (TC) as well as C-peptide kit had been purchased commercially (Wako, Osaka, Japan).

The procedure of making fat emulsion was described by Zou et al. [32]. One hundred milliliters of emulsified fat involved 40 milliliters of vanaspati, 30 milliliters of coconut oil, 10 milliliters of Tween 80,5 milliliters of propylene glycol and 15 milliliters of distilled water. The emulsion was kept at $4^{\circ} \mathrm{C}$ and was shaken with each application to obtain uniformity.

\section{Experimental plan}

The male Albino rats were separated into 4 groups each of which involved 12 rats resided as 6 rats in every plastic cage. The groups were labeled as:

Group I or Control group: Non-diabetic animals that were received the standard Laboratory Diet (LD).

Group II: Non-diabetic animals that were administrated 5 milliliters of fat-rich or Highly Fat (HF) emulsion.

Group III: Diabetic animals that were provided with standard Laboratory Diet (LD).

Group IV: Diabetic rats that were provided with 5 milliliters of highly fat emulsion.

The serum glucose levels (expressed in $\mathrm{mg} / \mathrm{dl}$ ) and serum C-peptide levels (expressed in $\mathrm{ng} / \mathrm{ml}$ ) as well as serum lipids (expressed in $\mathrm{mmol} / \mathrm{l}$ ) in form of Total Cholesterol (TC) and triglycerides (TG) were estimated under non-fasted conditions on the start of this work.

\section{Diabetes induction in rats}

Streptozotocin drug was injected intravenously in a dosage of 60 $\mathrm{mg} / \mathrm{kg}$. B.W in two animal groups (labeled groups III \& IV). Diabetes was obtained in three days due to damage of pancreatic islet B-cells as stated by Karunanayake et al. [33].

All four groups of rats were retained in their cages under feeding control. The serum levels of C-peptide protein (in $\mathrm{ng} / \mathrm{ml}$ ), serum glucose (in $\mathrm{mg} / \mathrm{dl}$ ), serum triglycerides ( $\mathrm{TG}$; in $\mathrm{mmol} / \mathrm{l}$ ) and total cholesterol
(TC; in $\mathrm{mmol} / \mathrm{l}$ ) were measured , under non-fasted conditions, every 2 weeks for 4 months according to Bhuyan et al. [34] for evaluation of the effective role of fat rich diet on diabetes since the association of excess fat intake with glucose-insulin metabolic disruption contributing in the development of T2D as well as its association with hyperlipidemia evidenced by hypercholesterolemia and hypertriglyceridemia attributing for organ ischemia that may interfere with fatty acid oxidation and eventually fatty infiltration within the parenchymatous organs.

To adapt the animals for fat - rich oral intake, we increased gradually the dose of oral diet within the first five days from one into five milliliters to be stabilized and maintained thereafter at five milliliters daily dose. The animals administrated standard LD were received identical water volume through a tube inserted into the stomach while those, not treated with streptozotocin, were given the same isotonic saline volume. We daily monitored all animal groups to detect medicoclinical manifestations throughout the study.

\section{Estimation of levels of C-peptide protein, glucose, TG and TC in rat serum}

All animals were made unconscious by using ether anaethesia through communication with ether for 2 minutes which doesn't influence the values of serum glucose and C-peptide protein. Blood sample from each non-fasted rat tail was taken, put in a sterile tube and the serum is segregated by centrifugation and stored in a refrigerator at a temperature of $4^{\circ} \mathrm{C}$ to estimate the levels of serum glucose $(\mathrm{mg} /$ dl) and C-peptide protein $(\mathrm{ng} / \mathrm{ml})$, which respectively indicates the extent of diabetes and reflects the pancreatic function regarding the insulin synthesis, in addition to serum TC $(\mathrm{mmol} / \mathrm{l})$ and TG $(\mathrm{mmol} / \mathrm{l})$ ,that may reflect the association of fat- rich diet and/or uncontrolled diabetes with hyperlipidemia, in a way similar to that reported by Levi et al [35]. The blood sampling and serum estimation were performed on all diabetic and nondiabetic animals periodically every 15 days for 4 months as stated by Thulesen et al. [36].

\section{Histological examination}

Tissue specimens were taken from livers \& kidneys of rats and each specimen was divided into three parts; one was prepared as frozen tissue and cut into sections to be stained with red oil stain. Another part was immediately fixed into $10 \%$ formaldehyde saline and was used to make tissue blocks and tissue sections that were stained with hematoxylin \& eosin. Both stained frozen and paraffin tissue slides were evaluated microscopically to demonstrate qualitatively the histopathological changes and quantitatively by imaging analysis. The third part was processed for ultrastructural examination of the micrometric and very thin tissue stained sections using the transmission electron microscope for detection of ultrastructural pathologic changes.

\section{Statistical analytic study}

The data were expressed as the mean \pm SEM and represent the average values for the animals in the same group. Each analysis was repeated three times and the average was used to compare between the groups. These data were subjected to statistical analysis using SPSS Program performed in our Medical College Statistical Center, in order to display their significance. $\mathrm{P}$ values less than 0.05 were considered as indicative of significance

\section{Outcomes}

The study revealed significantly higher levels of serum glucose in 
Citation: El-Rashedy AHARH, Mostafa Wahdan MH, El-Sabban KAFR, Khadrawy MA, Abu-Amara TMM, et al. (2013) Role of Fat Feeding on the Diabetic Albino Rats. J Cytol Histol 4: 176. doi:10.4172/2157-7099.1000176

group IV than in group III $(\mathrm{p}<0.05)$ while the levels were being within normal in group II and control group (120-140 mg/dl). In addition, serum total cholesterol (TC) and triglycerides (TG) levels were much greater in group IV diabetic rats compared to groups II and III $(\mathrm{p}<0.05)$ while the control group had normal serum lipid levels (Normal TC was $<5.17 \mathrm{mmol} / \mathrm{l}$ and normal TG was $<1.7 \mathrm{mmol} / \mathrm{l}$ ). Moreover, much reduction in serum C-peptide protein levels had found in group IV in contrast to group III $(\mathrm{P}<0.05)$. The group II rats had insignificant slightly greater serum C-peptide protein levels $(\mathrm{p}>0.05)$ than control animal

\section{Serum Glucose}

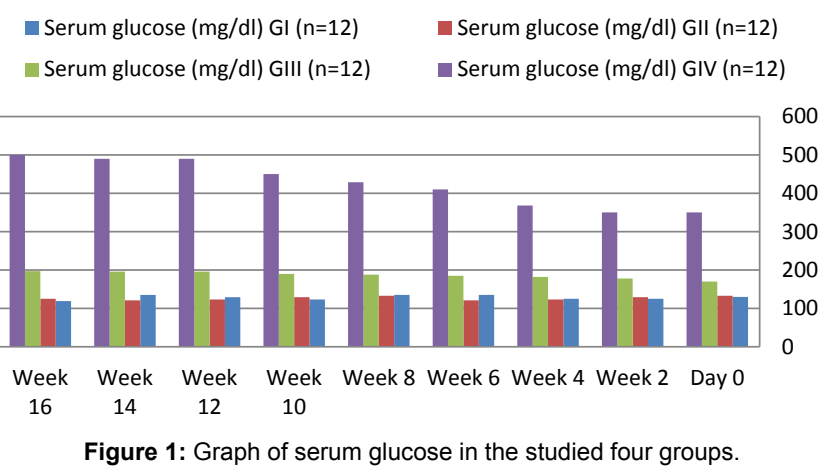

group which showed normal peptide values $(0.5-3.0 \mathrm{ng} / \mathrm{ml})$ (Tables 1 and 2 and Figures 1-4). In addition, light microscopic examination using the routine hematoxylin and eosin stain revealed more extensive intracellular fat accumulation; appearing as signet ring pattern due to displacement of hepatocytic nucleus against the cell membrane, in group IV (diabetic animals provided with high fatty food) (Figure 5D) than in group II (non-diabetics received high fatty food) (Figure 5B). This finding was confirmed by specific oil red stain that showed greater amount of intracellular red fat globules in group IV (Figure 6D) than in group II hepatic specimens (Figure 6B). Moreover, examination of routinely stained renal sections displayed much more fat vacuoles in the glomerular cellular cytoplasm and greater supranuclear fat vacuoles within the tubular lining cells of group IV (Figure 7D) than group II animals (Figure 7B). These features were evidenced, in oil red stained renal sections, by more intense red glomerular and tubular staining in group IV (Figure 8D) than in group II rats (Figure 8B). In addition, ultrastructural cytoplasmic black fat globules within the hepatocytes and renal tubular cells were more increased in diabetic fatty (Figure 9B and 9D) than in non-diabetic fatty animals. The intracellular fatty infiltration detected histopathologically in routinely and specifically stained hepatic (Figure 5C and 6C) and renal sections (Figure 7C and $8 \mathrm{C}$ ) as well as ultrastructurally was mild in group III (diabetic nonfatfed) rats. In contrast, control group animals didn't display neither hepatic (Figure 5A and 6A) nor renal (Figure 7A and 8A) parenchymal fatty infiltration in histopathological (Figure. 5A, 6A, 7A and 8A) and ultrastructural (Figure 9A and 9C) examination.

\begin{tabular}{|c|c|c|c|c|c|c|c|c|}
\hline \multirow{2}{*}{$\begin{array}{c}\text { Week } \\
\text { No; }\end{array}$} & \multicolumn{4}{|c|}{ Serum C-peptide } & \multicolumn{4}{|c|}{ Serum glucose (mg/dl) } \\
\hline & $\begin{array}{c}\text { GI\# } \\
(n=12)\end{array}$ & $\begin{array}{c}\text { GII\#\# } \\
(n=12)\end{array}$ & $\begin{array}{l}\text { GIII* } \\
(n=12)\end{array}$ & $\begin{array}{l}\text { GIV** } \\
(n=12)\end{array}$ & $\begin{array}{c}G I \\
(n=12)\end{array}$ & $G I^{*}(n=12)$ & GIII* (n=12) & $\begin{array}{l}\text { GIV*** } \\
(n=12)\end{array}$ \\
\hline Day 0 & $2.96 \pm 0.36$ & $3.05 \pm 0.57$ & $0.48 \pm 0.21$ & $0.24 \pm 0.12$ & $130 \pm 5$ & $133 \pm 7$ & $170 \pm 8$ & $350 \pm 2$ \\
\hline Week 2 & $2.97 \pm 049$ & $3.11 \pm 0.14$ & $0.46 \pm 0.32$ & $0.17 \pm 0.33$ & $125 \pm 5$ & $129 \pm 6$ & $178 \pm 9$ & $350 \pm 5$ \\
\hline Week 4 & $2.94 \pm 0.23$ & $3.02 \pm 0.05$ & $0.45 \pm 0.27$ & $0.14 \pm 0.2$ & $125 \pm 8$ & $123 \pm 6$ & $182 \pm 9$ & $368 \pm 2$ \\
\hline Week 6 & $2.98 \pm 0.11$ & $3.03 \pm 0.45$ & $0.44 \pm 0.13$ & $0.14 \pm 0.32$ & $135 \pm 4$ & $121 \pm 9$ & $185 \pm 4$ & $410 \pm 5$ \\
\hline Week 8 & $2.92 \pm 0.42$ & $3.03 \pm 0.16$ & $0.41 \pm 0.18$ & $0.12 \pm 0.25$ & $135 \pm 3$ & $133 \pm 7$ & $188 \pm 4$ & $429 \pm 9$ \\
\hline Week 10 & $2.95 \pm 0.21$ & $3.02 \pm 0.11$ & $0.41 \pm 0.13$ & $0.09 \pm 0.3$ & $123 \pm 8$ & $129 \pm 4$ & $190 \pm 5$ & $450 \pm 5$ \\
\hline Week 12 & $2.96 \pm 0.11$ & $3.04 \pm 0.26$ & $0.39 \pm 0.34$ & $0.08 \pm 0.41$ & $129 \pm 3$ & $123 \pm 5$ & $196 \pm 4$ & $490 \pm 2$ \\
\hline Week 14 & $2.98 \pm 0.25$ & $3.14 \pm 0.34$ & $0.35 \pm 0.11$ & $0.08 \pm 0.29$ & $135 \pm 2$ & $121 \pm 6$ & $196 \pm 9$ & $490 \pm 9$ \\
\hline Week 16 & $2.94 \pm 0.37$ & $3.02 \pm 0.18$ & $0.32 \pm 0.15$ & $0.06 \pm 0.13$ & $119 \pm 9$ & $125 \pm 2$ & $197 \pm 8$ & $500 \pm 2$ \\
\hline
\end{tabular}

The values in each group are represented as Means \pm Standard deviation. Significant $p$ values $(p<0.05)$ of both $C$-peptide and serum glucose were detected between $(*)$ and ( ${ }^{* *}$ ), however, insignificant $\mathrm{p}$ values ( $\mathrm{p}>0.05$ ) of $\mathrm{C}$-peptide were displayed between (G1*) and (G2 $\left.{ }^{\#}\right)$. Group I (control or nondiabetic fed on ordinary lab diet); Group II (non-diabetic fed on fatty diet); Group III (diabetic fed on ordinary lab diet); Group IV (diabetic fed on fatty diet); Day $0=$ The first day after fat feeding following induction of diabetes by injecting streptozotocin. Normal serum C-peptide was 0.5-3.0 ng/ml, serum glucose was $120-140 \mathrm{mg} / \mathrm{dl}$.

Table 1: Changes of serum C-peptide and serum glucose values during the study.

\begin{tabular}{|c|c|c|c|c|c|c|c|c|}
\hline \multirow{2}{*}{$\begin{array}{c}\text { Week } \\
\text { No; }\end{array}$} & \multicolumn{4}{|c|}{ TC (mmol/l) } & \multicolumn{4}{|c|}{ TG (mmol/l) } \\
\hline & $\begin{array}{c}G I \\
(n=12)\end{array}$ & $\begin{array}{c}G I^{*} \\
(n=12)\end{array}$ & $\begin{array}{l}\text { GIII* } \\
(n=12)\end{array}$ & $\begin{array}{l}\text { GIV*** } \\
(n=12)\end{array}$ & $\begin{array}{c}G I \\
(n=12)\end{array}$ & $\begin{array}{c}\text { GII* } \\
(n=12)\end{array}$ & $\begin{array}{c}\text { GIII* } \\
(n=12)\end{array}$ & $\begin{array}{l}\text { GIV*** } \\
(n=12)\end{array}$ \\
\hline Day 0 & $4.23 \pm 1.3$ & $4.57 \pm 0.19$ & $4.75 \pm 0.61$ & $4.89 \pm 0.3$ & $0.83 \pm 0.23$ & $0.86 \pm 0.09$ & $0.82 \pm 0.2$ & $0.92 \pm 0.16$ \\
\hline Week 2 & $4.88 \pm 0.08$ & $5.95 \pm 0.53$ & $5.79 \pm 0.52$ & $8.65 \pm 0.21$ & $0.78 \pm 0.26$ & $1.89 \pm 0.27$ & $1.84 \pm 031$ & $4.35 \pm 0.32$ \\
\hline Week 4 & $4.27 \pm 0.38$ & $5.98 \pm 0.44$ & $5.69 \pm 0.28$ & $9.84 \pm 0.32$ & $0.92 \pm 0.21$ & $1.87 \pm 0.32$ & $2.03 \pm 0.24$ & $4.68 \pm 0.13$ \\
\hline Week 6 & $4.26 \pm 1.5$ & $6.15 \pm 0.27$ & $5.87 \pm 0.34$ & $9.99 \pm 0.23$ & $0.74 \pm 0.15$ & $1.85 \pm 0.23$ & $1.93 \pm 0.11$ & $4.79 \pm 0.33$ \\
\hline Week 8 & $4.76 \pm 0.17$ & $6.23 \pm 0.57$ & $5.99 \pm 0.32$ & $9.62 \pm 0.12$ & $0.9 \pm 0.32$ & $1.91 \pm 0.14$ & $2.16 \pm 0.23$ & $4.83 \pm 0.14$ \\
\hline Week 10 & $4.42 \pm 0.31$ & $6.32 \pm 0.36$ & $5.97 \pm 0.14$ & $9.54 \pm 0.16$ & $0.97 \pm 0.35$ & $1.94 \pm 0.18$ & $2.18 \pm 0.21$ & $4.94 \pm 0.44$ \\
\hline Week 12 & $4.34 \pm 0.29$ & $6.35 \pm 0.17$ & $6.07 \pm 0.3$ & $10.59 \pm 0.4$ & $0.98 \pm 0.16$ & $1.96 \pm 0.05$ & $2.22 \pm 0.12$ & $5.11 \pm 0.18$ \\
\hline Week 14 & $4.53 \pm 0.14$ & $6.37 \pm 0.37$ & $6.15 \pm 0.47$ & $10.35 \pm 0.43$ & $0.93 \pm 0.27$ & $1.99 \pm 0.22$ & $2.23 \pm 0.16$ & $5.42 \pm 0.15$ \\
\hline Week 16 & $4.32 \pm 0.64$ & $6.39 \pm 0.32$ & 6. $19 \pm 0.2$ & $11.14 \pm 0.19$ & $0.99 \pm 0.23$ & $2.11 \pm 0.13$ & $2.24 \pm 0.19$ & $5.87 \pm 0.18$ \\
\hline
\end{tabular}

The values in each group are represented as Means \pm Standard deviation. Significant $p$ values $(p<0.05)$ were detected between $(*)$ and $(* *)$ since the second week's values of the study and thereafter. Group I (control or nondiabetic fed on ordinary lab diet); Group II (non-diabetic fed on fatty diet); Group III (diabetic fed on ordinary lab diet); Group IV (diabetic fed on fatty diet); Day $0=$ The first day after fat feeding following induction of diabetes by the injecting streptozotocin. Normal serum TC was $<5.17$ $\mathrm{mmol} / \mathrm{l}$ and normal TG was $<1.7 \mathrm{mmol} / \mathrm{l}$.

Table 2: Changes of serum total cholesterol (TC) and triglycerides (TG) values during the study: 
Citation: El-Rashedy AHARH, Mostafa Wahdan MH, El-Sabban KAFR, Khadrawy MA, Abu-Amara TMM, et al. (2013) Role of Fat Feeding on the Diabetic Albino Rats. J Cytol Histol 4: 176. doi:10.4172/2157-7099.1000176

\section{Serum C-peptide}

$\begin{array}{ll}\text { - Serum C - peptide GI }(n=12) & \text { Serum C - peptide GII }(n=12) \\ \text {-Serum C - peptide GIII }(n=12) & \text { Serum C - peptide GIV }(n=12)\end{array}$

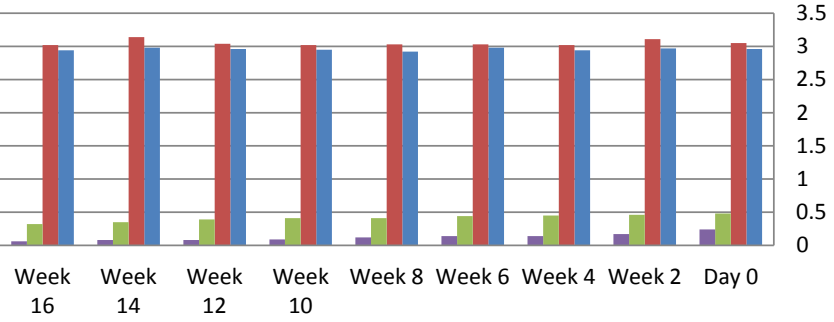

Figure 2: Graph of serum C-peptide in the studied four groups.

\section{Serum Total Cholesterol ( $\mathrm{mmol} / \mathrm{l})$}

\begin{abstract}
- Total cholesterol (mmol/l) G I ( $\mathrm{n=12}$ - Total cholesterol (mmol/l) GII ( $\mathrm{n=12}$
- Total cholesterol (mmol/l) GIII ( $\mathrm{n}=12) \quad$ - Total cholesterol (mmol/l) GIV ( $\mathrm{n}=12)$
\end{abstract}

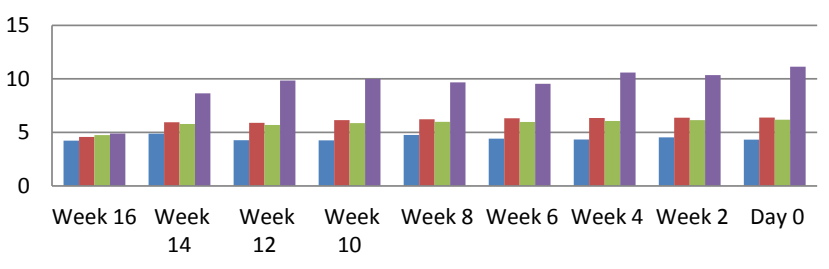

Figure 3: Graph of serum total cholesterol in the studied four groups.

\section{Serum Triglycerides}

\begin{tabular}{|c|c|}
\hline - TG $(\mathrm{mmol} / \mathrm{l}) \mathrm{Gl}(\mathrm{n}=12)$ & - TG (mmol) GII $(\mathrm{n}=12)$ \\
\hline TG (mmol/l) GIII $(n=12)$ & TG (mmol/l) GIV $(n=12)$ \\
\hline
\end{tabular}

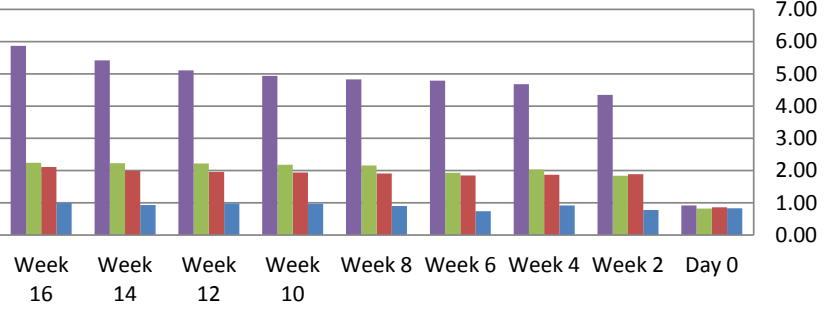

Figure 4: Graph of serum triglycerides in the studied four groups.

\section{Discussion}

Excessive overweight as well as T2D are apparently worldwide and are considered critical obstacles for the personal health. The type of food and lack of muscular exercise are accused and regarded as risk factors in the incidence of these diseases. Thus, the intake of fats and oils in developing countries is an important area of research due to fast increasing prevalence of these above mentioned metabolic diseases among these countries. Available data show an increase in supply and demand of various oils in developing countries. However, rare information is available concerning the total fat relationship with fat type in case of obesity and non insulin - dependent diabetes in most growing countries. Metabolic effects of consumption of specific oils are used widely in some developing countries (e.g. high saturated fat ghee or palm oil). Finally, head-to-head comparison of various oils regarding effects on diabetes, lipids, blood pressure and other cardiovascular risk factors is required [2].

This study revealed higher hyperglycaemic levels as well as greater hypercholesterolaemic and hypertriglyceraedemic values in fat-fed diabetic rats than diabetic ones fed on laboratory diet. However, fatfed non-diabetic rats showed normal serum glucose levels despite of high serum TC and TG levels. Hypertriglyceridemia resulting from the amplified triglyceride production has an indirect effect on impaired gluconeogenesis aggravated by chronically low insulin levels. Also, impairment of free fatty acids oxidation and increased their synthesis from acetone released in ketoacidotic hyperglycemia are associated with fatty accumulation within the liver causing its
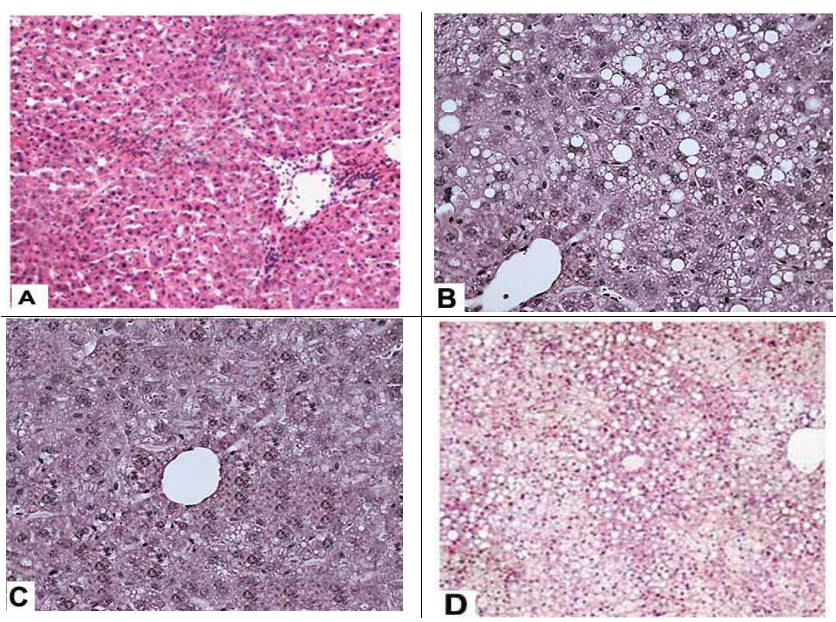

Figure 5: Photomicrographs of liver specimens showing more extensive parenchymal fatty infiltration (prominent fat vacuoles) in a group IV rat (D) as compared to a group II one (B). Liver specimen of group III animal (C) showed mild or minimal fatty infiltration while that of control rat $(A)$ was devoid of the fatty infiltration (Hematoxylin and Eosin stain ; A \& D x $100, B$ \& C x200).
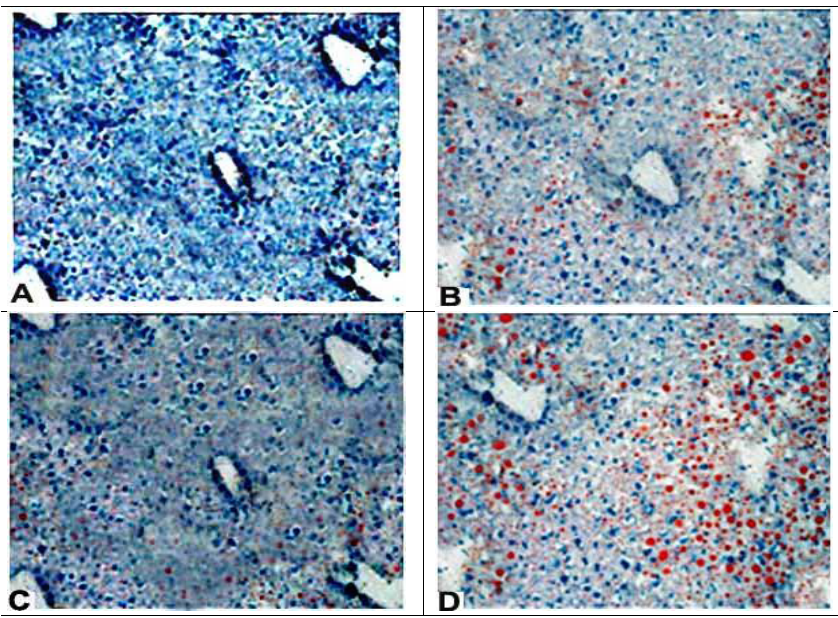

Figure 6: Photomicrographs of liver specimens showing more quantitatively and qualitatively extensive parenchymal fatty infiltration (prominent red fat globules) in group IV rat (D) as compared to group II (B). Liver specimen of the group III animal $(C)$ showed mild or minimal fatty infiltration while that of control rat $(\mathrm{A})$ was devoid of the fatty infiltration (Oil red stain $\times 100$ ). 
Citation: El-Rashedy AHARH, Mostafa Wahdan MH, El-Sabban KAFR, Khadrawy MA, Abu-Amara TMM, et al. (2013) Role of Fat Feeding on the Diabetic Albino Rats. J Cytol Histol 4: 176. doi:10.4172/2157-7099.1000176

characteristic enlargement of the liver. These results coincided with those detected by Boden [18] and Yang et al. [37] who reported an increase in certain intestinal peptide degrading enzyme in association with fat-rich nutrition and suggested the association of this intestinal enzyme with the development of non insulin - dependent diabetes. Moreover, Djousse et al. [38] discovered little and contradictory information regarding the relationship between serum glucose levels and omega three polyunsaturated fatty acids although these fatty acids were evidenced to decrease the hazards of myocardial ischemia and termination of life. They observed that fish-derived, but not vegetablederived, omega three polyunsaturated fatty acids enhanced the diabetic incidence. Furthermore, Kaushik et al. [39] compared the maximal and the minimal amounts of these fatty acids and observed in their study

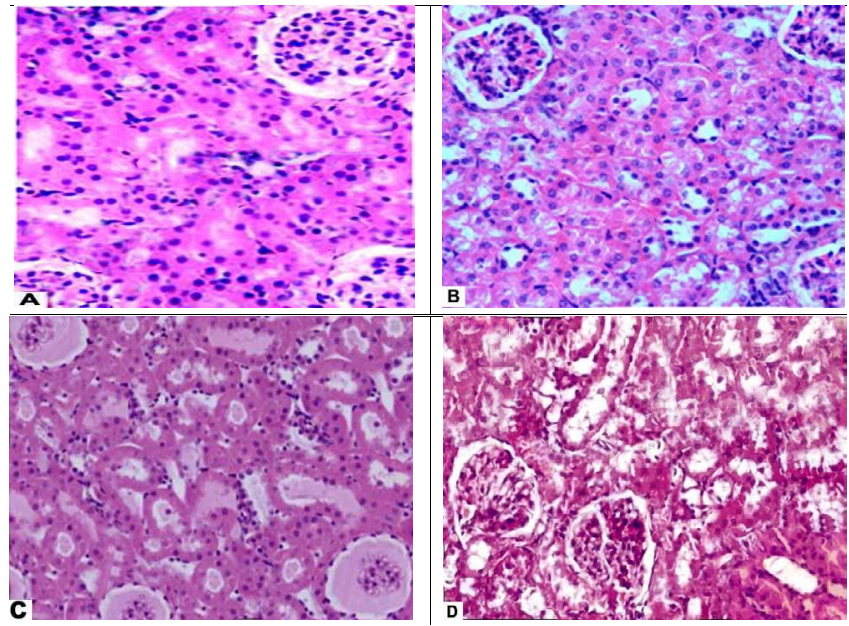

Figure 7: Photomicrographs of renal specimens showing more quantitatively and qualitatively extensive fatty infiltration (prominent supranuclear fat vacuoles in the tubular lining cells as well as glomerular vacuolization) in group IV rat (D) as compared to group II one (B). Renal specimen of group III (C) showed mild or minimal glomerular and tubular fatty infiltration while that of control rat (A) was devoid of the fatty infiltration (Hematoxylin and Eosin stain; $x$ 150).
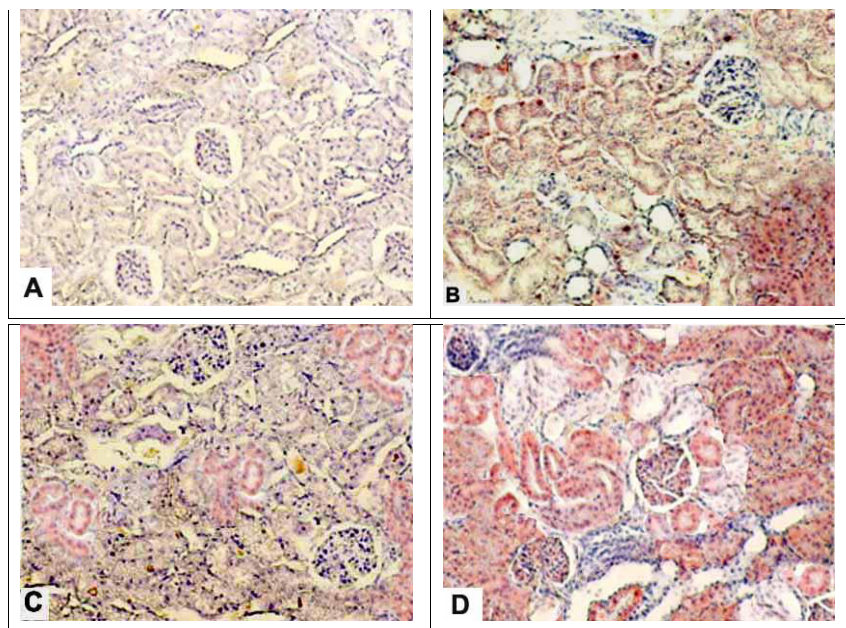

Figure 8: Photomicrographs of renal specimens showing more qualitatively extensive glomerular and tubular fatty infiltration (dark red stained epithelial cells) as well as a quantitative accumulation in group IV animal (D) as compared to a group II one (B). Renal specimen of a group III rat (C) showed mild or minimal quantitative and qualitative fatty infiltration (faint red stained tubular lining) while that of control rat $(A)$ was devoid of the fatty infiltration (Oil red stain $\times 100$ ).
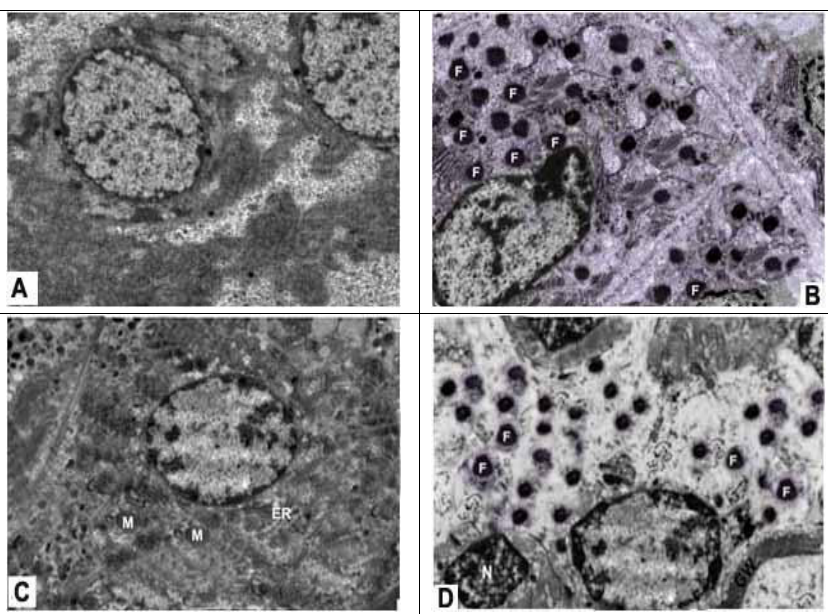

Figure 9: Electromicrographs of hepatic and renal specimens of group I and group IV animals. There were extensive black fat globules $(F)$ indented the nucleus of hepatocyte $(B)$ as well as extensive black fat globules $(F)$ detected above the nucleus $(\mathrm{N})$ of renal tubular cells with thickening of the glomerular wall (GW) caused by diabetes mellitus (D). In contrast, no fatty globules were detected within the hepatocytes (A) nor within the renal tubular cells (C) that showed normal mitochondria (M) and endoplasmic reticulum (ER) (Transmission electron microscope $\times 10,000$ ).

that these polyunsaturated fatty acids had been accompanied in their larger, but not smaller, doses with a moderately high risky diabetic incidence. Wang et al. [40] and Hodge et al. [41] reported contradictor information that the diabetic incidence had no relation to fish-derived polyunsaturated fatty acids.

A significant decline in serum very low density lipoprotein level was displayed with the intake of omega three- rich food while the serum low density lipoprotein level had been insignificantly affected with this food regimen [42]. By contrary, Griffin et al. [43] detected raised low density lipoprotein following omega three management of type 2 diabetics because these fatty acids reduced intermediately dense lipoproteins' breakdown with consequent much more quantity of low density lipoproteins. In addition, Karlstrom et al. [42] found that high density lipoprotein cholesterol, on average, and apolipoprotein A-I were mostly not affected with supplementary omega three administration of T2D category.

Furthermore, our study revealed much reduced serum C-peptide levels in fat-fed diabetic rats in contrast to non fat - fed diabetics. Also, the fat-fed non diabetic rats showed slightly increased C-peptide levels while this serum peptide levels were within normal in the control rats. The results agreed with those reported by Hills and Brunskill [24] who mentioned that the serum C-peptide insulin byproduct reflected the amount of liberated insulin by beta pancreatic cells. In addition, they stated that with inapparent type of diabetes mellitus, testing of serum C-peptide protein could be resorted to determine whether to be T1D or T2D. They mentioned that the pancreas does not make any insulin in T1D which is thus accompanied with a low amount of serum C-peptide protein which is elevated or being within normal value in T2D as well as in obesity.

Moreover, serological testing of C-peptide protein aids in assessment the etiology of hypoglycemia whether due to an external insulin overdosage for diabetic therapy or to the presence of functioning endocrine neoplasm releasing ample amount of insulin. In hypoglycemia caused by insulin overdosage, the serum peptide level is 
decreased while hypoglycemia resulting from functioning neoplasm is accompanied with elevated serum peptide level [23].

Our study, as well, showed more intensely detected histopathological and ultrastructural features of parenchymal fat accumulation within the liver and kidneys of diabetic fat-fed rats than those of nondiabetic fat-fed animals. Furthermore, intracellular fatty infiltration was found in a mild degree within hepatic and renal parenchyma of diabetic nonfat-fed rats and was absent in nondiabetic nonfat-fed control animals. These findings were identical to those mentioned by Muhlfeld et al. [44] as well as by Buettner et al. [45]. They found negative apolipoprotein B staining within hepatocytes or in renal tissue of the normolipidemic control mice and mentioned that positive fatty infiltration detected in renal and hepatic tissue of diabetic mice, in particular, may resort to dysfunctional fat removal mechanism by the hepatocytes as well as via the mesangiocytic route. Furthermore, they focused on the environmental agents as well as personal habits especially lack of muscular activity as substantial risk factors in diabetes. Also, obesity and its related disorders like dyslipidaemia, diabetes as well as hypertension have actually accompanied excessive hypercaloric feeding. Moreover, Gauthier et al. [46] and Romestaing et al. [47] mentioned that fat-rich food intake can augment firstly the internal organic lipid content particularly inside parenchymatous organs such as liver, kidney and heart and can secondly result in a consequential fat accumulation peripherally and circumferentially under the skin. Therefore, excessive overweight, resistance to the secreted insulin especially intrahepatic and organic dysfunction may be obtained. The amount of intrahepatic deposited fat may drop but can enlarge with long-term fat-rich nutrition.

Renal damage occurring with hypertriglyceridemia and hypercholesterolemia is suggested to be firstly caused by easy intracellular passage of fat aided by a deficient membranous barrier between the capillary circulating blood and glomerular mesangium together with the perforated vascular lining endothelium in the kidney. As a result the serum oxidized lipoproteins that gain their intracellular entrance can bind to the mesangial cells leading to their rapid multiplication, promotion of the release of chemicals mediating the inflammatory process (the same could occur within the liver) and activation of glycoprotein synthesis of the mesangial matrix. Secondly, oxidized harmful lipoprotein forms vascular atheromatous plaques that can narrow the lumen causing impaired renal perfusion. Thirdly, the deposited renal fats promote the release of chemotactic agents that attracts macrophages and provide them the gate to enter into the glomeruli, renal tubules and interstitium. Thus, these three mechanisms supposed in the affected animals can mediate renal injury. Also, a significant correlation had been found between the glomerular macrophage content and expression of transforming growth factor beta (TGF- $\beta$ ) which is considered as an essential cytokine facilitating the formation of matrix extracellularly [44].

\section{Conclusion}

The findings of this study can conclude that hyperlipidemia may lead to a significant renal and hepatic injury particularly with diabetes that is considered as one of the metabolic disorders related to a disturbance in fat metabolism. Moreover, the fatty diet may aggravate the diabetic manifestations \& therefore may enhance its complications.

\section{Recommendation}

In view of rapid rise of incidence of type 2 diabetes worldwide, so several knowledge plans illustrating its modifiable and non-modifiable risk factors as well as multiple popular health instructions particularly regarding the promotion of widespread use of healthy balanced nutrition together with establishment of the importance of physical activity are required to diminish the prevalence and complications of this disease.

In addition, further studies correlating the role of obesity and hyperlipidemia with diabetes together with highlighting their biochemical effects on liver and renal functions are essentially recommended in the near future.

\section{References}

1. Popkin BM, Lu B, Zhai F (2002) Understanding the nutrition transition: measuring rapid dietary changes in transitional countries. Public Health Nutr 5: 947-953.

2. Misra A, Singhal N, Khurana L (2010) Obesity, the metabolic syndrome, and type 2 diabetes in developing countries: role of dietary fats and oils. J Am Coll Nutr 29: 289S-301S.

3. Maire B, Lioret S, Gartner A, Delpeuch F (2002) Nutritional transition and noncommunicable diet-related chronic diseases in developing countries. Sante 12: 45-55.

4. Tucker KL, Buranapin S (2001) Nutrition and aging in developing countries. J Nutr 131: 2417S-2423S.

5. Galgani JE, Uauy RD, Aguirre CA, Díaz EO (2008) Effect of the dietary fat quality on insulin sensitivity. Br J Nutr 100: 471-479.

6. Misra A, Khurana L (2008) Obesity and the metabolic syndrome in developing countries. J Clin Endocrinol Metab 93: S9-S30.

7. Misra A, Chowbey P, Makkar BM, Vikram NK, Wasir JS (2009) Consensus statement for diagnosis of obesity, abdominal obesity and the metabolic syndrome for Asian Indians and recommendations for physical activity, medical and surgical management. J Assoc Physicians India 57: 163-170.

8. Meyer KA, Kushi LH, Jacobs DR Jr, Folsom AR (2001) Dietary fat and incidence of type 2 diabetes in older lowa women. Diabetes Care 24: 1528-1535.

9. Steyn NP, Mann J, Bennett PH, Temple N, Zimmet P, et al. (2004) Diet, nutrition and the prevention of type 2 diabetes. Public Health Nutr 7: 147-165.

10. International Monetary Fund (2009): Emerging and Developing Economies List. World Economic Outlook Database.

11. Misra A, Khurana L, Isharwal S, Bhardwaj S (2009) South Asian diets and insulin resistance. Br J Nutr 101: 465-473.

12. Dugee O, Khor GL, Lye MS, Luvsannyam L, Janchiv O, et al. (2009) Association of major dietary patterns with obesity risk among Mongolian men and women. Asia Pac J Clin Nutr 18: 433-440.

13. Narasinga Rao BS (2010) Nutrient requirement and safe dietary intake for Indians. NFI Bull 31:1-5.

14. Marshall JA, Bessesen DH (2002) Dietary fat and the development of type 2 diabetes. Diabetes Care 25: 620-622.

15. Centers for Disease Control and Prevention (2011) National diabetes fact sheet: national estimates and general information on diabetes and pre-diabetes in the United States. Atlanta, GA: US Department of Health and Human Services, Centers for Disease Control and Prevention.

16. van Dam RM, Willett WC, Rimm EB, Stampfer MJ, Hu FB (2002) Dietary fat and meat intake in relation to risk of type 2 diabetes in men. Diabetes Care 25 417-424.

17. Blonska M, Lin X (2011) NF-kB signaling pathways regulated by CARMA family of scaffold proteins. Cell Res 21: 55-70.

18. Boden G (2011) Obesity, insulin resistance and free fatty acids. Curr Opin Endocrinol Diabetes Obes 18: 139-143.

19. Van Beek M, Oravecz-Wilson KI, Delekta PC, Gu S, Li X, et al. (2012) Bcl10 links saturated fat overnutrition with hepatocellular NF-kB activation and insulin resistance. Cell Rep 1: 444-452.

20. Deevska GM, Nikolova-Karakashian MN (2011) The twists and turns of sphingolipid pathway in glucose regulation. Biochimie 93: 32-38. 
Citation: El-Rashedy AHARH, Mostafa Wahdan MH, El-Sabban KAFR, Khadrawy MA, Abu-Amara TMM, et al. (2013) Role of Fat Feeding on the Diabetic Albino Rats. J Cytol Histol 4: 176. doi:10.4172/2157-7099.1000176

21. Deng Y, Johnson DR, Guan X, Ang CY, Ai J, et al. (2010) In vitro gene regulatory networks predict in vivo function of liver. BMC Syst Biol 4: 153-159.

22. Turban S, Hajduch E (2011) Protein kinase C isoforms: mediators of reactive lipid metabolites in the development of insulin resistance. FEBS Lett 585: 269274.

23. Mughal RS, Scragg JL, Lister P, Warburton P, Riches K (2010) Cellular mechanisms by which proinsulin C-peptide prevents insulin-induced neointima formation in human saphenous vein. Diabetologia; 53: 1761-1771.

24. Hills CE, Brunskill NJ (2008) Intracellular signaling by C-peptide. Exp Diabetes Res; 635158- 635167.

25. Wahren J, Ekberg K, Jörnvall $H$ (2007) C-peptide is a bioactive peptide. Diabetologia 50: 503-509.

26. Samnegård B, Jacobson SH, Jaremko G, Johansson BL, Ekberg K, et al. (2005) C-peptide prevents glomerular hypertrophy and mesangial matrix expansion in diabetic rats. Nephrol Dial Transplant 20: 532-538.

27. Nordquist L, Brown R, Fasching A, Persson P, Palm F (2009) Proinsulin C-peptide reduces diabetes-induced glomerular hyperfiltration via efferen arteriole dilation and inhibition of tubular sodium reabsorption. Am J Physiol Renal Physi 297: F1265-1272.

28. Wahren J, Ekberg K, Jörnvall H (2007) C-peptide and Neuropathy in Type 1 Diabetes. Diabetologia 48: 69-77.

29. Nordquist L, Wahren J (2009) C-Peptide: the missing link in diabetic nephropathy? Rev Diabet Stud 6: 203-210.

30. Luppi P, Cifarelli V, Tse H, Piganelli J, Trucco M (2008) Human C-peptide antagonises high glucose-induced endothelial dysfunction through the nuclear factor-kappaB pathway. Diabetologia 51: 1534-1543.

31. Saravanan N, Haseeb A, Ehtesham NZ, Ghafoorunissa (2005) Differential effects of dietary saturated and trans-fatty acids on expression of genes associated with insulin sensitivity in rat adipose tissue. Eur J Endocrinol 153: 159-165.

32. Zou Y, Li J, Lu C, Wang J, Ge J, et al. (2006) High-fat emulsion-induced rat model of nonalcoholic steatohepatitis. Life Sci 79: 1100-1107.

33. Karunanayake EH, Hearse DJ, Mellows G (1975) The metabolic fate and elimination of streptozotocin. Biochem Soc Trans 3: 410-414.

34. Bhuyan BK, Kuentzel SL, Gray LG, Fraser TJ, Wallach D, et al. (1974) Tissue distribution of streptozotocin (NSC-85998). Cancer Chemother Rep 58: 157165.

35. Levi JA, Wiernik PH, Diggs CH (1977) Combination chemotherapy of advanced previously treated Hodgkin's disease with streptozotocin, CCNU, adriamycin and bleomycin. Med Pediatr Oncol 3: 33-40.

36. Thulesen J, Orskov C, Holst JJ, Poulsen SS (1997) Short-term insulin treatment prevents the diabetogenic action of streptozotocin in rats. Endocrinology 138 : $62-68$

37. Yang J, Campitelli J, Hu G, Lin Y, Luo J, et al. (2007) Increase in DPP-IV in the intestine, liver and kidney of the rat treated with high fat diet and streptozotocin. Life Sci 81: 272-279.

38. Djoussé L, Gaziano JM, Buring JE, Lee IM (2011) Dietary omega-3 fatty acids and fish consumption and risk of type 2 diabetes. Am J Clin Nutr 93: 143-150.

39. Kaushik M, Mozaffarian D, Spiegelman D, Manson JE, Willett WC, et al. (2009) Long-chain omega- 3 fatty acids, fish intake, and the risk of type 2 diabetes mellitus. Am J Clin Nutr 90: 613-620.

40. Wang L, Folsom AR, Zheng ZJ, Pankow JS, Eckfeldt JH, ARIC Study Investigators (2003) Plasma fatty acid composition and incidence of diabetes in middle-aged adults: the Atherosclerosis Risk in Communities (ARIC) Study. Am J Clin Nutr 78: 91-98.

41. Hodge AM, English DR, O'Dea K, Sinclair AJ, Makrides M, et al. (2007) Plasma phospholipid and dietary fatty acids as predictors of type 2 diabetes: interpreting the role of linoleic acid. Am J Clin Nutr 86: 189-197.

42. Karlström BE, Järvi AE, Byberg L, Berglund LG, Vessby BO (2011) Fatty fish in the diet of patients with type 2 diabetes: comparison of the metabolic effects of foods rich in n-3 and n-6 fatty acids. Am J Clin Nutr 94: 26-33.

43. Griffin MD, Sanders TA, Davies IG, Morgan LM, Millward DJ (2009): Effects of altering the ratio of dietary n-6 to n-3 fatty acids on insulin sensitivity, lipoprotein size, and postprandial lipemia in men and postmenopausal women aged 45-70 y: the OPTILIP Study. Am J Clin Nutr 84: 1290-1298.

44. Mühlfeld AS, Spencer MW, Hudkins KL, Kirk E, LeBoeuf RC, et al. (2004) Hyperlipidemia aggravates renal disease in B6.ROP Os/+ mice. Kidney Int 66 : 1393-1402.

45. Buettner R, Schölmerich J, Bollheimer LC (2007) High-fat diets: modeling the metabolic disorders of human obesity in rodents. Obesity (Silver Spring) 15: 798-808.

46. Gauthier MS, Favier R, Lavoie JM (2006) Time course of the development of non-alcoholic hepatic steatosis in response to high-fat diet-induced obesity in rats. Br J Nutr 95: 273-281.

47. Romestaing C, Piquet MA, Bedu E, Rouleau V, Dautresme M, et al. (2007) Long term highly saturated fat diet does not induce NASH in Wistar rats. Nutr Metab (Lond) 4: 4. 